\title{
TNF- $\alpha$ AND IL-6 IMMUNOHISTOCHEMISTRY IN RAT RENAL TISSUE EXPERIMENTALY INFECTED WITH Leptospira interrogans SEROVAR CANICOLA
}

\author{
MARINHO M (1), MONTEIRO CMR (1), PEIRÓ JR (2), MACHADO GF (2), \\ OLIVEIRA-JÚNIOR IS (3)
}

(1) Department of Animal Health and Production, Dentistry School, FOA, São Paulo State University, UNESP, Araçatuba, São Paulo State, Brazil; (2) Department of Clinics, Surgery and Animal Reproduction, Dentistry School, FOA, São Paulo State University, UNESP, Araçatuba, São Paulo State, Brazil; (3) Inflammatory Mediators Laboratory, Division of Geriatrics and Gerontology, Department of Medicine, Federal University of São Paulo, São Paulo, São Paulo State, Brazil.

\begin{abstract}
Leptospirosis is a public health problem worldwide and its etiology remains unclear. Its pathogenesis involves a complex interaction between host and infecting microorganism. The inflammatory reaction that controls the infection process also underscores many pathophysiological events occurring in leptospirosis. We investigated the presence of tumor necrosis factor- $\alpha$ (TNF- $\alpha$ ) and interleukin- 6 (IL-6) in renal tissues by immunohistochemical and histopathological examination in animals experimentally inoculated with Leptospira serovar Canicola. All the tests were carried out $2,7,14,21$ or 28 days after inoculation. Although TNF- $\alpha$ and IL-6 had been detected in tissues throughout the observation period, these cytokines appeared more intensely during the initial phase of infection. Therefore, both TNF- $\alpha$ and IL-6 were associated with the immunopathogenesis of leptospirosis. This profile suggests a high immunocellular response throughout the early infection stages followed by subsequent humoral response.
\end{abstract}

KEY WORDS: leptospirosis, immunohistochemistry, IL-6, TNF-a, mice.

CONFLICTS OF INTEREST: There is no conflict.

FINANCIAL SOURCE: The State of São Paulo Research Foundation (FAPESP), financial aid process n. 2002/10139-1.

\section{CORRESPONDENCE TO:}

MÁRCIA MARINHO, Universidade Estadual Paulista, Rua Clóvis Pestana, 793, CEP 16050-680, Araçatuba, São Paulo, Brasil. Phone: +55 183636 1382. Fax 5518 2633-6487. Email: mmarinho@fmva.unesp.br. 


\section{INTRODUCTION}

Leptospirosis is a zoonotic infection caused by spirochetes of the genus Leptospira, which are common in the tropics and in developing countries (1). Rodents, particularly rats, are the most frequent worldwide disseminators of this disease. Leptospira can enter the human body through skin wounds, including very small scratches, as well as through intact mucous membranes of the mouth, nose and eyes (7). Immune response to leptospirosis is mainly humorally mediated and involves opsonization of leptospires by macrophages and neutrophils (10). TNF- $\alpha$ has been detected in the peripheral blood of patients with leptospirosis (5). Tajiki and Salomão (15) found that TNF- $\alpha$ was associated with both disease severity and mortality in leptospirotic patients. Marinho et al. (8) studied the role of cytokines, nitric oxide (NO) and hydrogen peroxide $\left(\mathrm{H}_{2} \mathrm{O}_{2}\right)$ in the immunopathology of leptospirosis in genetically selected Balb/c mice, measured by high or low antibody production. An endotoxin-like substance is present in the cell walls of leptospires, which could induce cytokine synthesis and contribute to their pathogenicity, as well as to hemodynamic disturbance $(15,17)$. The present study aimed to detect TNF- $\alpha$ and IL6 production in renal tissues by immunohistochemical staining and evaluate whether these cytokines would be associated with the immunopathogenesis of leptospirosis.

This study was approved by the local Animal Care and Use Committee of São Paulo State University.

Thirty Balb/c mice - male and female, aged between 4 and 8 weeks - were randomly divided into six equal groups of five mice each. Animals were infected with $10^{3}$ viable Leptospira interrogans serovar Canicola kindly provided by the Oswaldo Cruz Foundation (FIOCRUZ). Leptospires were previously cultured in Fletcher medium for seven days (18).

Mice from each group were sacrificed on days 2, 7, 14, 21 and 28 post-inoculation (PI). After sedation with Thiopentax® (Cristália, Brazil), 30 to $100 \mathrm{mg} / \mathrm{kg}$ body weight, the thoracic cavity was opened and the left ventricle was punctured. Phosphatebuffered saline (PBS) solution (at $4^{\circ} \mathrm{C}$ ) was then slowly injected until organs were clearly pale. Immediately thereafter, the kidneys were removed and rapidly sectioned transversely, placed in cryoprotective solution, frozen in liquid nitrogen and then stored at $-80^{\circ} \mathrm{C}$ until required for final processing in a freezing microtome. 
Viscera from healthy and infected mice were fixed in $10 \%$ neutral-buffered formalin and embedded in paraffin. Serial 5 - $\mu$ m-thick sections were cut and stained with hematoxylin and eosin (HE).

Tissue was sliced (6 to $10 \mathrm{~mm}$ ) at the cryostat temperature of around -18 to $-20^{\circ} \mathrm{C}$. Sections were air dried at room temperature for at least 30 minutes, and then immersion-fixed in acetone for 1 to 2 minutes at room temperature. Subsequently, endogenous peroxidase activity was blocked for 10 minutes with $1 \% \mathrm{H}_{2} \mathrm{O}_{2}$ diluted in PBS. Slides were then washed with PBS containing $1 \%$ bovine serum albumin (BSA) and background staining was blocked with powdered skim milk (3\% in phosphate buffered saline). Sections were incubated overnight at $4^{\circ} \mathrm{C}$ with anti-TNF- $\alpha$ or anti-IL6 (Santa Cruz Biotechnology, USA) and then were washed three times for 5 minutes each in PBS plus $1 \%$ BSA and incubated at room temperature for 45 minutes with biotinylated antibody. After being washed three times, in PBS plus $1 \%$ BSA, for 5 minutes each, sections were incubated with $A B$ complex (Vector Laboratories, USA) for 45 minutes. Sections were washed again and the reaction was revealed by DAB (Sigma-Aldrich, USA) and finally counterstained with Mayer's hematoxylin. The control slide was not incubated with the primary antibody. Tissue sections from at least one mouse of each group were processed at the same time. Photomicrographs were taken with a $\mathrm{BX} 50 \AA$ microscope (Olympus America Inc., USA) equipped with an automatic camera system.

Histological alterations in renal and hepatic sections of Balb/c mice were highly similar throughout the observation period, except for different injury degrees and compromised tissue area. On the second day after infection, the epithelial cells surrounding Bowman's capsule were enlarged and a mild mononuclear cell infiltrate was detected in the hilar region. Proliferation of endothelial cells with apparent nucleus in the glomerulus was also evident. By seven days after inoculation, a marked tubular degeneration had occurred in the medullary region, with a moderate proliferation of epithelial cells from Bowman's capsule accompanied by a mild infiltrate in the hilar region. On the $14^{\text {th }}$ and $21^{\text {st }}$ days after infection, histological lesions had become more intensified, showing extensive and pronounced hydropic degenerative changes in medullar and tubular kidney areas. Intense multiplication and hypertrophy of epithelial cells of Bowman's capsule as well as glomerular hypercellularity were also found. Twenty days after inoculation, microscopic renal 
lesions were similar to those described above; however, these degenerative areas were distributed throughout renal parenchyma and were more intense in the medullar area. Interstitial nephritis is the basic lesion of leptospirosis and is observed even in patients without clinical renal manifestations. Nevertheless, 21 days after inoculation, lesion patterns in mice kidneys involved proliferative glomerulonephritis without significant interstitial inflammation.

TNF- $\alpha$ was detected from the initial phase of infection until the $14^{\text {th }}$ day postinoculation. However, IL-6 was present until day 28 in the present study. Glomerularpositive staining for IL-6 (A) and TNF- $\alpha$ (C) in kidney sections of mice inoculated with Leptospira interrogans is shown in Figure 1. We noticed the strongest positive staining for both cytokines on day 7 post-inoculation compared with other observation days. However, on the $7^{\text {th }}$ day, the tubular epithelial cells and intersticial tissue showed a faint positive staining for IL-6 and TNF- $\alpha$. 

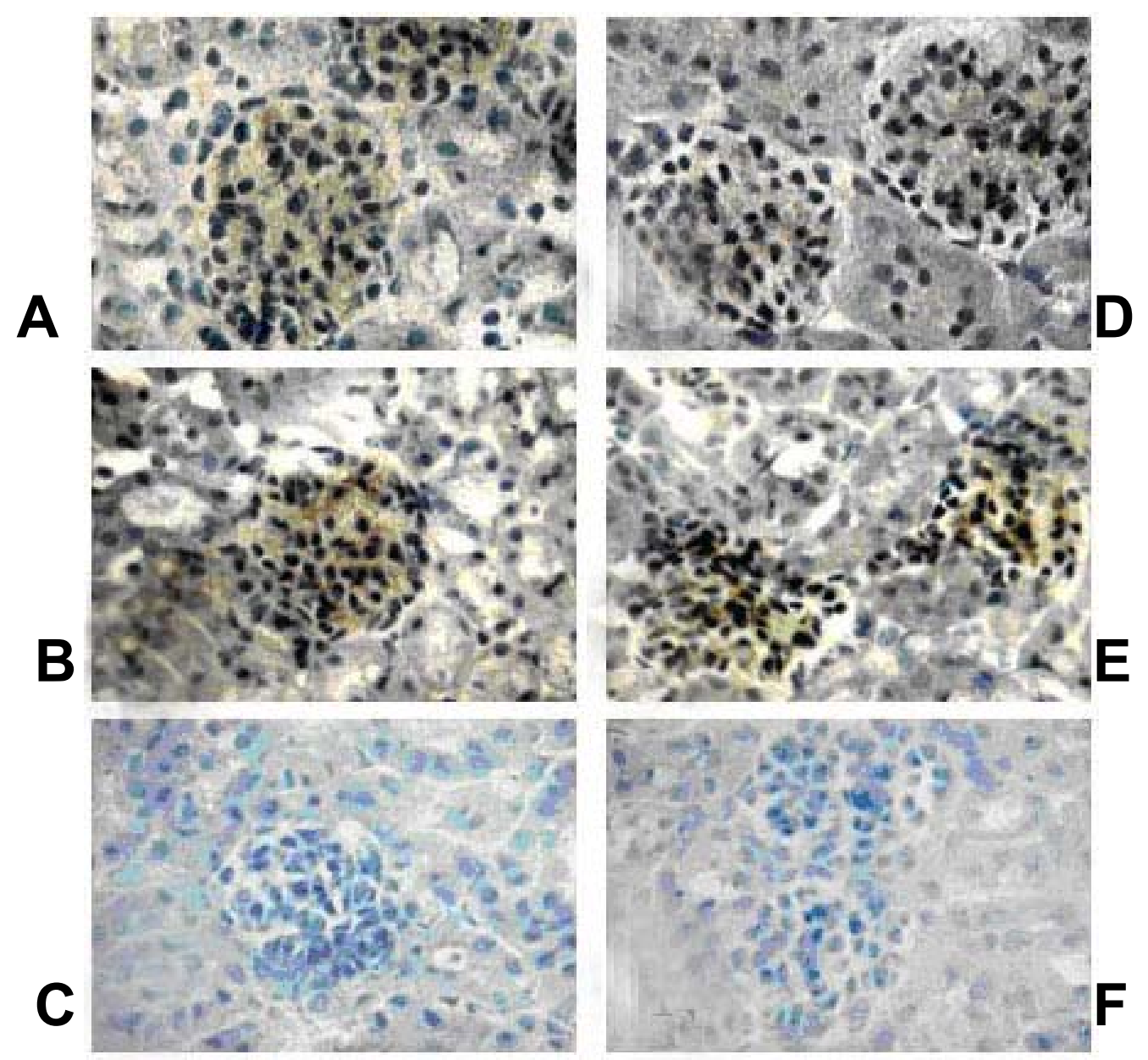

Figure 1. Weak glomerular-positive staining to IL-6 at day $2(\mathbf{A})$ and more intense at day 7 (B). Frame D shows weaker positive staining for TNF- $\alpha$ than the intensity observed at day 7. Frames $\mathbf{C}$ and $\mathbf{F}$ are respectively controls for IL-6 and TNF- $\alpha(\mathbf{A}$, $\mathrm{B}$ and $\mathrm{C}$ revealed by $\mathrm{DAB}$, objective $40 \mathrm{x}$ ).

As in classical bacterial sepsis of different etiology, plasma cytokine levels are elevated in severe leptospirosis (4). During the acute phase, TNF- $\alpha$ levels are associated with the severity of the disease $(5,15)$. TNF- $\alpha$ is produced mainly by monocyte macrophages stimulated with lipopolysaccharide (LPS) and other agents. After LPS injection, TNF- $\alpha$ is produced in blood, reaches a peak within 60 to 90 minutes after inoculation and disappears in subsequent hours (13). In another study, Marinho et al. (9) found that TNF-a was detected during the first days of infection (from $7^{\text {th }}$ to $21^{\text {st }}$ ). TNF- $\alpha$ could be detected in the first 6 hours of incubation, and its levels gradually decreased in the following 24 to 72 hours. On the contrary, IL-10 was detectable at low levels 6 hours after infection and progressively increased in the 
next 24 to 72 hours (4). This sequence of events observed in vitro resembles cytokine patterns observed in patients with sepsis $(2,16)$.

In the present study, TNF- $\alpha$ production was demonstrated by immunohistochemistry from the $4^{\text {th }}$ to the $14^{\text {th }}$ day of infection. Although this process is not directly related to the host protection, these facts can be better understood from ascertaining the profile of leptospirosis infection, which is characterized as a biphasic illness: the first phase, septicemic or leptospiremic, usually lasts 4 to 7 days; and the second is an immune stage characterized by the appearance of circulating immunoglobulin $M$ antibodies (6). The presence of a toxin, or a toxic factor, in leptospirosis has been suspected for decades, but has never been confirmed. Marinho et al. $(8,9)$ suggested that cytokines, such as TNF- $\alpha$ and IL-6, may play a dubious role in the immunopathogenesis of leptospirosis. Recently, Nally et al. (11) demonstrated the presence of $\lg \mathrm{M}, \lg \mathrm{G}$ and $\lg \mathrm{A}$ and $\mathrm{C}_{3}$ along the alveolar basement membrane, thus suggesting that an autoimmune process constitutes the etiology of fatal hemorrhagic complications due to leptospirosis. A strong immunostaining of both IL- 6 and TNF- $\alpha$ was observed in addition to glomerular hypercellularity in Balb/c mice inoculated with Leptospira interrogans serovar Canicola. IL-6 production was enhanced by renal mesangial cells, a fact that may be associated with mesangial proliferation or interstitial tissue injury as proposed by Suzuki et al. (14). These cells had adhered to the glomerular capillary wall, between endothelial cells and the basal lamina. The histophysiological mechanism of the mesangial cells is still unknown. A possible mechanism involving these cells could be the removal of residues that remained bound to the glomerular capillary wall during filtration. IL-6 is secreted from intestinal macrophages (12) and is the main cytokine involved in the induction of acute-phase response (3). These cytokines are proteins that allow hepatic cells to communicate with other cells and tissues. Cytokine production is stimulated by cell differentiation, receptor expression and cell-mediated immunity (19). We concluded that during leptospirosis there is a high cellular immune response in the initial phase of the disease followed by subsequent humoral response. The innovative findings from this study indicate that cytokine production, such as TNF- $\alpha$ and IL-6, should be associated with the immunopathogenesis of leptospirosis. 


\section{ACKNOWLEDGEMENTS}

This study was supported by the State of São Paulo Research Foundation (FAPESP) process n. 2002/10139-1.

\section{REFERENCES}

1 BHARTI AR., NALLY JE., RICALDI JN., MATTHIAS MA., DIAZ MM., LOVETT M., LOVETT PN., GILMAN RH., WILLIG MR., GOTUZZO E., VINETZ JM. Leptospirosis: a zoonotic disease of global importance. Lancet Infect. Dis., 2003, 3, 757-71.

2 CASEY LC. Immunologic response to infection and its role in septic shock. Crit. Care Clin., 2000,16,193-214.

3 CZARKOWSKA-PACZEK B., BARTLOMIEJCZYK I., GABRYS T., PRZYBYLSKI J., NOWAK M., PACZEK L. Lack of relationship between interleukin-6 and CRP levels in healthy male athletes. Immunol. Lett., 2005, 1, 136-40.

4 DIAMENT D., BRUNIALTI MKC., ROMERO EC., KALLAS EG., SALOMÃO R. Peripheral blood mononuclear cell activation induced by Leptospira interrogans glycoprotein. Infect. Immunol., 2002, 70, 1677-87.

5 ESTAVOYER JM., RACADOT E., COVETDIC G., LEROY J., GROSPERRIN L. Tumor necrosis factor in patients with leptospirosis. Rev. Infect. Dis., 1991, 13, 12456.

6 HUNTER MD., PEREIRA HCP., TANAKA RM. Pneumonia por Leptospirose. J. Pneumol., 2002, 28, 229-32.

7 KOBAYASHI Y. Clinical observation and treatment of leptospirosis. J. Infect. Chemother., 2001, 7, 59-68.

8 MARINHO M., LANGONI H., OLIVEIRO SL., LIMA VMF., PEIRÓ JR., PERRI SH., CARREIRA R. Role of cytokines, $\mathrm{NO}$, and $\mathrm{H}_{2} \mathrm{O}_{2}$ on the immunopathology of Leptospirosis in genetically selected mice. J. Venom. Anim. Toxins incl. Trop. Dis., 2005, 12, 198-212.

9 MARINHO M., SILVA C., LIMA VMF., PEIRÓ JR., PERRI SH. Cytokine and antibody production during murine leptospirosis. J. Venom. Anim. Toxins incl. Trop. Dis., 2006, 12, 595-603.

10 MITCHISON M., BULACH DM., VINH T., RAJAKUMAR K., FAINE S., ADLER B. Identification and caracterizacion of the dTDP-Rhamnose biosynthesis and transfer 
genes of the Lipopolysaccharide-related rfb locus in Leptospira interrogans serovar Copenhageni. J. Bacteriol., 1997, 179, 1262-7.

11 NALLY JE., CHANTRANUWAT C., WU XY., FISHBEIN MC., PEREIRA MM., SILVA JJ., BLANCO DR., LOVETT MA. Alveolar septal deposition of immunoglobulin and complement parallels pulmonary hemorrhage in a guinea pig model of severe pulmonary leptospirosis. Am. J. Pathol. , 2004, 164, 1115-27.

12 NUNEZ A., GOMEZ-VILLAMANDOS JC., SANCHEZ-CORDON PJ., FERNANDEZ DE MARCO M., PEDRERA M., SALGUERO FJ., CARRASCO L. Expression of proinflammatory cytokines by hepatic macrophages in acute classical swine fever. J. Comp. Pathol., 2005, 133, 23-32.

13 SALOMÃO R., RIGATO O., PIGNATARI AC., FREUDENBERG MA.,GALANOS C. Bloodstream infections: Epidemiology, pathophysiology and therapeutic perspectives. Infection, 1999, 27, 1-11.

14 SUZUKI D., MIYAZAKI M., NAKA R., KOJI T., YAGAM M., JINDE K., ENDOH M., NAMOTO Y., SAKAI H. In situ hybridization of interleukin 6 in diabetes nefropathy. Diabetes, 1995, 44, 1233-8.

15 TAJIKI MH., SALOMÃO R. Association of plasma levels of tumor necrosis factor $\alpha$ with severity of diseases and mortality among patients with leptospirosis. C. Infect. Dis., 1996, 23, 1177-8.

16 VAN DER POLL T., VAN DEVENTER SJ. Cytokines and anticytokines in pathogenesis of sepsis. Infect. Dis. Clin. North Am., 1999, 13, 413-26.

17 VINETZ JM. Leptospires. Curr. Opin. Infect. Dis., 1997, 10, 357-361.

18 YASUDA PH., HOSHINO-SHIMIZU S., YAMASHIRO-KANASHIRO EH., BRITO T. Experimental leptospirosis (L. interrogans serovar icterohaemorrhagiae) of guinea pig: leptospiral antigen, gamma globulin and complement C3 detection in the kidney. Exp. Pathol., 1986, 29, 35-43.

19 ZAJKOWSKA JM., HERMANOWSKA-SZPAKOWICZ T., PANCEWICZ SA., KONDRUSIK M., SWIERZBINSKA R., GRYGORCZUK S. Serum concentration of TNF-alpha and IL-1 beta in patients with chronic hepatitis $C$ treated with interferon alpha-a preliminary report. Rocz. Akad. Med. Bialymst., 2002, 47, 276-86. 